\title{
Effect of implantational delay on transfer of rat embryos to mice
}

\author{
A. J. Copp and J. Rossant \\ Department of Zoology, South Parks Road, Oxford OXI 3PS, U.K.
}

\begin{abstract}
Summary. Rat and mouse blastocysts were transferred to the uteri of ovariectomized mice, maintained by progesterone for a few days and induced to implant by oestradiol administration. Mouse implantation sites contained normal embryos; all rat embryos were retarded, although some had developed to the egg-cylinder stage.
\end{abstract}

\section{Introduction}

Mammalian embryos can sometimes complete their preimplantation development after transfer to the oviduct or uterus of another species (Briones \& Beatty, 1954; Averill, Adams \& Rowson, 1955; Tarkowski, 1962; Chang, 1965, 1966; Brinster \& TenBroeck, 1969; Lawson, Adams \& Rowson, 1972; Beyer \& Zeilmaker, 1973). However, implantation has only rarely been observed after heterospecific transfers, and postimplantation development has not proceeded beyond the earliest stages (Tarkowski, 1962; Blaha \& De Feo, 1964; Chang \& Pickworth, 1969) except for transfers between sheep and goats when advanced embryos have been obtained (Warwick \& Eerry, 1949; Lopyrin, Loginova \& Karpov, 1951). Similarly, interspecific aggregation chimaeras between rat and mouse (Rossant, 1976) and bank vole and mouse (Mystkowska, 1975) show limited development, although when rat inner cell masses are injected into mouse blastocysts improved postimplantation development results (Gardner \& Johnson, 1975), suggesting that trophectoderm-uterine incompatibility may be responsible for the peri-implantation embryonic death occurring after heterospecific transfer. Kirby (1969) briefly outlined a method for obtaining postimplantation development of rat embryos in recipient mice which involved the transfer of rat blastocysts into mouse uteri held in implantational delay. After several days of progesterone administration, implantation was induced by oestradiol injection. Kirby reported that a normal 14-day rat embryo was obtained in this way, but gave no experimental details. Since such a method would be of great value in the study of the development of interspecific chimaeras, we have attempted to repeat Kirby's experiment.

\section{Materials and Methods}

Blastocysts were obtained from random-bred CFLP mice and CFHB rats (Anglia Laboratory Animals Ltd) as described previously (Rossant, 1976). Two experiments were performed. In the first, female CFLP mice were bilaterally ovariectomized and subsequently given a daily s.c. injection of $1 \mathrm{mg}$ progesterone (Intervet) in $0.05 \mathrm{ml}$ arachis oil. On the day after ovariectomy, 4-6 rat blastocysts were transferred to one uterine horn of each recipient mouse, the contralateral horn receiving an equal number of mouse blastocysts. On the 4th and 5 th days after transfer, $10 \mathrm{ng}$ oestradiol benzoate (Intervet) were included in the daily injection. Implantation began on the day following the second oestradiol injection, and the mice were killed on the 8th day after transfer, when early egg-cylinder stage embryos would be expected. In the second experiment, the method described by Kaufman, Barton \& Surani (1977) for improving the postimplantation development of mouse parthogenones was followed. Mice on Day 3 of pseudopregnancy were bilaterally ovariectomized immediately after receiving rat and mouse embryos. Two days later, daily s.c. injections of $1 \mathrm{mg}$ progesterone in arachis oil were initiated and $20 \mathrm{ng}$ oestradiol benzoate were included on Days 6, 7 and 8 after transfer. Recipients were killed the following day. Any implantation sites in either experiment were fixed in formol-acetic-alcohol, processed and embedded in paraffin wax (Orsini, 1962), serially sectioned at $6 \mu \mathrm{m}$, and stained with haemalum and eosin. 


\section{Results}

The results are summarized in Table 1. All mouse embryos were normal egg-cylinders (PI. 1, Fig. 1). Although some rat embryos developed to the egg-cylinder stage (PI. 1, Fig. 2), these appeared retarded and disorganized in comparison with those obtained after transfer of rat blastocysts to the rat uterus (Rossant, 1976). Some rat embryos consisted only of vacuolated endoderm plus trophoblast giant cells (Pl. 1, Fig. 3) while others showed no recognizable structure and were classified as disorganized blastocysts.

Table 1. The results of transfer of rat and mouse blastocysts to ovariectomized mice treated with progesterone and oestradiol (see text)

\begin{tabular}{lcccccccc}
\hline & $\begin{array}{c}\text { No. of } \\
\text { embryos } \\
\text { trans- } \\
\text { ferred }\end{array}$ & $\begin{array}{c}\text { No. of } \\
\text { recipients }\end{array}$ & $\begin{array}{c}\text { No. of } \\
\text { recipients } \\
\text { pregnant }\end{array}$ & $\begin{array}{c}\text { No. of } \\
\text { implant- } \\
\text { ations }\end{array}$ & $\begin{array}{c}\text { Normal } \\
\text { egg } \\
\text { cylinders }\end{array}$ & $\begin{array}{c}\text { Retarded } \\
\text { egg } \\
\text { cylinders }\end{array}$ & $\begin{array}{c}\text { Endoderm } \\
\text { plus } \\
\text { trophec- } \\
\text { toderm }\end{array}$ & $\begin{array}{c}\text { Dis- } \\
\text { organized } \\
\text { blasto- } \\
\text { cysts }\end{array}$ \\
\hline $\begin{array}{l}\text { Experiment } \\
\begin{array}{l}\text { Mouse } \\
\text { Rat }\end{array}\end{array}$ & 25 & 5 & 4 & 5 & 5 & - & - & - \\
$\begin{array}{l}\text { Experiment } \\
\text { Mouse }\end{array}$ & 25 & 5 & 9 & - & 3 & 2 & 4 \\
Rat & 24 & 5 & 4 & 12 & 12 & - & - & - \\
\hline
\end{tabular}

Proportion of normal mouse embryos implanted (17/17) is significantly greater than proportion of normal rat embryos (0/17), $\chi^{2}=30 \cdot 1,1$ d.f., $P<0.001$.

Combined implantation rates for Experiments $1(14 / 50)$ and $2(20 / 48)$ do not differ significantly, $\chi^{2}=1 \cdot 46,1 \mathrm{~d} . \mathrm{f}$., $0.2<P<0.3$.

\section{Discussion}

Rat blastocysts induced decidualization of the mouse uterus as frequently as did mouse blastocysts (Table 1) and all implantations contained trophoblastic giant cells. Nevertheless, normal rat postimplantation development did not occur, and the range of structures seen (Pl, 1, Figs 2 and 3) was very similar to that found previously after transfer of rat blastocysts to oviducts of mice on Day 1 of pseudopregnancy (Tarkowski, 1962) or to uteri of mice on Day 3 of pseudopregnancy (Rossant, 1976). In a review of implantation Surani (1977) mentioned a similar failure to promote interspecific development after transfer of rat embryos to ovariectomized mice: development was not observed beyond the implanting blastocyst stage. Although Kaufman et al. (1977) have successfully used the method employed here in Exp. 2 to promote the postimplantation development of parthenogenetic embryos in the mouse, it is clear that implantational delay does not permit prolonged postimplantation development of rat blastocysts transferred to the mouse. This suggests that the inability of rat blastocysts to develop normally in the mouse uterus is not simply due to insufficient time for adjustment to the foreign environment but may indicate a more fundamental species-specific interaction. Failure to establish intimate trophectodermal-mucosal contacts at the normal time could be involved (Tarkowski, 1962), perhaps due to the presence of species-specific trophectodermal and uterine epithelial cell surface components. A role for the maternal immune system cannot be ruled out, however, since the transfer of mouse blastocysts to the uteri of irradiated, pseudopregnant rats has produced normal 7-day mouse embryos (Zeilmaker, 1971).

In conclusion, we have been unable to confirm Kirby's observation and believe that the failure of postimplantation development after interspecific transfer, at least in rodents, is due to some as yet undefined trophectoderm-uterine incompatibility which cannot be overcome by prolonging the preimplantation existence of the blastocyst in the foreign uterine environment. 


\section{PLATE 1}
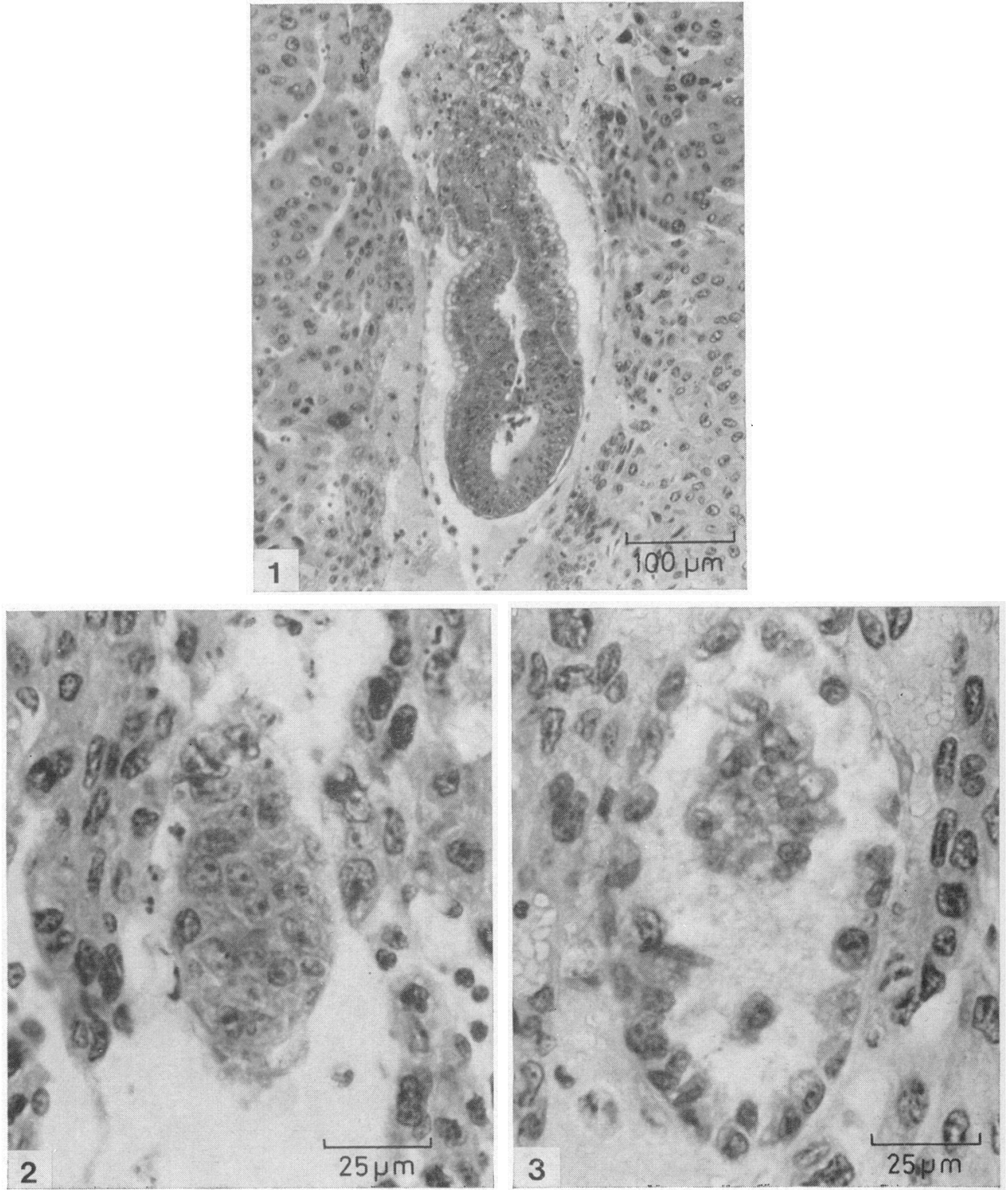

Fig. 1. Section of normal mouse egg-cylinder produced in Exp. 1.

Fig. 2. Retarded rat egg-cylinder produced in Exp. 2.

Fig. 3. Rat embryo produced in Exp. 1 showing a trophectoderm vesicle lined by scattered distal endoderm cells and containing a central group of vacuolated endoderm cells. 
We thank Dr R. L. Gardner for valuable discussion. This work was supported by the Medical Research Council. A.J.C. is a Christopher Welch Scholar and J.R. is a Beit Memorial Research Fellow.

\section{References}

Averill, R.L.W., Adams, C.E. \& Rowson, L.E.A. (1955) Transfer of mammalian ova between species. Nature, Lond. 176, 167-168.

BeYer, G. \& ZFILMAKer, G.H. (1973) Development of mouse and rat zygotes following transfer to nonsynchronized rat and mouse oviducts. J. Reprod. Fert. 33, 141-143.

Blaha, G.C. \& DE Feo, V.J. (1964) Interspecies ova transfer between hamsters and rats. Anat. Rec. 148, 261, Abstr.

Brinster, R.L. \& TenBroeck, J.T. (1969) Blastocyst development from mouse preimplantation embryos in the rabbit Fallopian tube. J. Reprod. Fert. 19, 417-423.

BRIONES, H. \& BEATTY, R.A. (1954) Interspecific transfer of rodent eggs. J. exp. Zool. 125, 99-118.

Chang, M.C. (1965) Artificial insemination of Snowshoe hares (Lepus americanus) and the transfer of their fertilized eggs to the rabbit (Oryctolagus cuniculus). J. Reprod. Fert. 10, 447-449.

Chang, M.C. (1966) Reciprocal transfer of eggs between rabbit and ferret. J. exp. Zool. 161, 297-303.

Chang, M.C. \& Pickworth, S. (1969) Egg transfer in the laboratory animal. In The Mammalian Oviduct, pp. 389-405. Eds E. S. E. Hafez \& R. J. Blandau. University of Chicago Press.

GARDNER, R.L. \& JoHNSON, M.H. (1975) Investigation of cellular interaction and deployment in the early mammalian embryo using interspecific chimaeras between the rat and mouse. In Cell Patterning (Ciba Found. Symp. No. 29), pp. 183-200. Associated Scientific Publishers, Amsterdam.

Kaufman, M.H., Barton, S.C. \& Surani, M.A.H. (1977) Normal postimplantation development of mouse parthenogenetic embryos to forelimb bud stage. Nature, Lond. 265, 53-55.
KIRBY, D.R.S. (1969) Hybrid and interspecies pregnancies. In Immunology and Reproduction, p. 205. Ed. R. G. Edwards. I.P.P.F., London.

LAwSON, R.A.S., ADAMS, C.E. \& Rowson, L.E.A. (1972) The development of sheep eggs in the rabbit oviduct and their viability after retransfer to ewes.J. Reprod. Fert. 29, 105-116.

Lopyrin, A.I., Loginova, N.V. \& Karpov, P.L. (1951) The effect of changed conditions on growth and development in lambs. Sov. Zootekh. 6, 83-95.

Mystkowska, E.T. (1975) Development of mousebank vole interspecific chimaeric embryos. $J$. Embryol. exp. Morph. 33, 731-744.

ORsiNI, M.W. (1962) Technique of preparation, study and photography of benzyl benzoate cleared material for embryological studies. J. Reprod. Fert. 3, 283287.

RossaNT, J. (1976) Investigation of inner cell mass determination by aggregation of isolated rat inner cell masses with mouse morulae. J. Embryol. exp. Morph. 36, 163-174.

SurANi, M.A.H. (1977) Cellular and molecular approaches to blastocyst uterine interactions at implantation. In Development in Mammals, Vol. 1, pp. 245-305. Ed. M. H. Johnson. Elsevier/North Holland Biomedical Press, Amsterdam.

TARKowsKI, A.K. (1962) Interspecific transfers of eggs between rat and mouse. J. Embryol. exp. Morph. 10, 476-495.

WARWICK, B.L. \& BERRY, R.O. (1949) Intergeneric and intraspecific embryo transfers in sheep and goats. J. Hered. 40, 297-303.

Z.EILMAKER, G.H. (1971) Blastocyst proliferation in rats and mice; effects of immunization and irradiation. J. Reprod. Fert. 27, 495-496.

Received 8 June 1977 